\title{
PENGARUH MOTIVASI DAN DISIPLIN KERJA \\ TERHADAP KINERJA PEGAWAI \\ (Studi pada Pegawai Negeri Sipil di Dinas Sosial Kabupaten Kendal)
}

\author{
Fidyah Yuli Ernawati, Siti Rochmah \\ Program Studi Manajemen STIE SEMARANG
}

\begin{abstract}
The purpose of this study was to find out the Motivation and Work Discipline partially or simultaneously on Employee Performance (studies on Civil Servants at the Kendal District Social Service). The method used in this research is Multiple Regression Analysis. This research was conducted on Civil Servants in the Kendal Social Service Office of Kendal. The results showed that Motivation had a significant positive effect on Employee Performance (studies on Civil Servants in the Kendal District Social Service), Work Discipline had a significant positive effect on Employee Performance (Study on Civil Servants in the Kendal District Social Service).
\end{abstract}

Keywords: Employee Performance, motivation, work discipline

\begin{abstract}
ABSTRAK
Tujuan dari penelitian ini adalah untuk mengetahui Motivasi dan Disiplin Kerja secara parsial atau simultan terhadap Kinerja Pegawai (studi pada Pegawai Negeri Sipil di Dinas Sosial Kabupaten Kendal). Metode yang digunakan dalam penelitian ini adalah Analisis Regresi Berganda, Penelitian ini dilakukan pada Pegawai Negeri Sipil di Dinas Sosial Kabuoaten Kendal. Hasil penelitian menunjukan bahwa Motivasi berpengaruh positif signifikan terhadap Kinerja Pegawai (studi pada Pegawai Negeri Sipil di Dinas Sosial Kabupaten Kendal), Disiplin Kerja berpengaruh positif signifikan terhadap Kinerja Pegawai (Studi pada Pegawai Negeri Sipil di Dinas Sosial Kabupaten Kendal).
\end{abstract}

\section{Kata Kunci: Kinerja Pegawai, motivasi, disiplin kerja}

\section{PENDAHULUAN}

Sumber daya manusia merupakan penggerak utama jalannya kegiatan sebuah organisasi, maju mundurnya suatu organisasi ditentukan oleh keberadaan sumber daya manusianya. Sehingga sumber daya manusiaatau pegawai dalam sebuah organisasi menjadi perhatian penting dalam rangka usaha mencapai keberhasilan organisasi. Keberhasilan suatu organisasi dalam mencapai tujuan organisasi ditentukan oleh kinerja pegawai. Kemampuan pegawai mengerjakan pekerjaan yang menjadi tanggung jawabnya menjadi tolok ukur pencapaian tujuan organisasi.

Persaingan global saat ini, dunia kerja sangat membutuhkan orang yang biasa berfikir untuk maju, cerdas, inovatif dan mampu berkarya dengan semangat tinggi dalam menghadapi 
kemajuan zaman. Berbagai organisasi, berusaha meningkatkan kinerja dari seluruh elemen yang ada dalam organisasi dengan tujuan mencapai kelangsungan hidup organisasi.Sumber daya manusia yang dalam hal ini adalah para pegawai pada sebuah organisasi, tentunya berusaha bekerja dengan kemampuan yang mereka miliki agar dapat mencapai kinerja yang diinginkan organisasi tersebut.

Kinerja merupakan suatu hasil kerja yang dicapai seseorang dalam melaksanakan tugas-tugas yang dibebankan kepadanya yang didasarkan atas kecakapan, pengalaman dan kesungguhan serta waktu. Peningkatan kinerja pegawai dalam suatu organisasi sangat diperlukan agar tujuan yang dinginkan oleh organisasi dapat direaliasikan dengan baik. Untuk itu pegawai sebaiknya diperlakukan sebagai partner kerja dan bukan sebagai pekerja semata. Untuk mendapatkan kinerja pegawai sesuai dengan yang diharapkan, organisasi mempunyai tugas untuk memberikan dorongan kepada para pegawai, agar mereka bekerja dengan giatnya sehingga mencapai target organisasi. Secara teori berbagai definisi tentang motivasi biasanya terkandung keinginan, harapan, kebutuhan, tujuan, sasaran, dorongan dan insetif. Pegawai bekerja dengan harapan akan memperoleh upah/gaji yang dapat untuk memenuhi kebutuhan tersebut.Kinerja suatu organisasi akan meningkat apabila terdapat kerjasama dan hubungan yang baik antara pimpinan dan pegawainnya.

Disiplin kerja merupakan salah satu aspek dalam sistem kerja yang harus diperhatikan oleh sebuah organisasi atau perusahaan untuk meningkatkan kinerja atau produktivitas sebuah organisasi. Sehingga baik atau tidaknya disiplin kerja yang dimiliki pegawai tersebut dipengaruhi oleh baik atau tidaknya sistem pendisiplinan yang dijalankan oleh sebuah organisasi. Bila Pegawai memiliki disiplin kerja yang tinggi, diharapkan akan mampu menyelesaikan tugas dengan cepat dan tepat sehingga kinerja yang dihasilkan akan baik.

Dinas Sosial Kabupaten Kendal merupakan intsansi pemerintah yang bekerja memberikan pelayanan jaminan sosial dan korban bencana kepada masyarakat. Seperti Visi Dinas Sosial Kabupaten Kendal "MENJADI LEMBAGA PROFESIONAL DALAM MEWUJUDKAN KESEJAHTERAAN SOSIAL BAGI PENYANDANG MASALAH KESEJAHTERAAN SOSIAL (PMKS) YANG DIDUKUNG OLEH POTENSI dan SUMBER KESEJAHTERAAN SOSIAL (PSKS) YANG HANDAL”. Visi tersebut mengandung maksud bahwa dalam 5 (lima) tahun kedepan penyelenggaraan pembangunan kesejahteraan sosial diarahkan untuk mewujudkan kesejahteraan sosial bagi PMKS yang didukung oleh PSKS yang handal, dengan berpedoman kepada 4 (empat) pilar pelayanan kesejahteraan sosial.Oleh karena itu para PNS dan Tenaga ahli pembantu staff dituntut untuk mengikuti semua peraturan yang ada,bekerja secara disiplin, dan bekerja giat untuk 
mendapatkan target yang sudah ditentukan disetiap awal tahun. Dinas Sosial Kabupaten Kendal membuat beberapa kebijaksanaan yang harus diikuti seluruh pegawai kantor yaitu seperti upacara dipagi hari setiap hari senin, jadwal absensi yang ketat dengan mengunakan finger print dan absensi tulis tangan, jam masuk jam 08.00 am, dan diharapkan pegawai tidak menyepelekan absensi dan tidak melakukan kesalahan dalam bekerja. Apabila pegawai melanggar semua kebijkasanaan yang sudah ditetapkan pemerintah,maka akan ada konsekuensi yang harus diterima oleh pegawai yang melanggar. Dinas Sosial Kabupaten Kendal dalam aktivitasnya berusaha untuk selalu menekankan kepada seluruh sumber daya manusianya untuk dapat mencapai kinerja yang baik, Dimana manfaat dari kinerja tersebut tidak hanya dirasakan individu tetapi juga dirasakan oleh institusi yang bersangkutan. Dinas Sosial Kabupaten Kendal juga berusaha membantu para korban bencana yang sedang mengalami bencana dengan baik atau program lainnya.Pegawai merasa target yang ditetapkan terlalu tinggi, karena jumlah yang di dapat setiap tahunnya bersumber dari para masyarakat yang membutuhkan pelayanan sosial sadar akan kewajibannya sebagai masyarakat. Mereka merasa target terlalu tinggi untuk dicapai dengan fasilitas yang disediakan. Mereka merasa dengan target yang begitu tinggi sangat kecil kemungkina dapat mencapai target dengan kekurangan yang ada di kantor tersebut.

Berdasarkan uraian di atas, penulis tertarik untuk melakukan penelitian yang berjudul "Pengaruh Motivasi dan Disiplin Kerja Terhadap Kinerja Pegawai (Studi Pada PNS Dinas Sosial Kabupaten Kendal)".

\section{MASALAH PENELITIAN}

Berdasarkan uraian latar belakang diatas, maka permasalahan yang akan dibahas dalam penelitian ini adalah apakah motivasi dan disiplin kerja berpengaruh positif dan signifikan terhadap kinerja pegawai pada Kantor Dinas Sosial Kabupaten Kendal. Adapun tujuan dari penelitian ini adalah untuk mengetahui dan menganalisis pengaruh motivasi dan disiplin kerja terhadap kinerja pegawai pada Kantor Dinas Sosial Kabupaten kendal.

\section{KAJIAN TEORITIS}

\section{a. Kinerja Pegawai}

Kinerja merupakan hasil kerja secara kualitas dan kuantitas yang dicapai oleh seseorang pegawai dalam melaksanakan tugasnya sesuai dengan tanggung jawab yang diberikan kepadanya. Menurut Bastian (2001) kinerja adalah gambaran mengenai tingkat pencapaian pelaksanaan tugas dalam suatu organisasi, dalam upaya mewujudkan sasaran, 
tujuan, misi, dan visi organisasi tersebut. Mangkunegara (2011) kinerja adalah hasil kerja secara kualitas dan kuantitas yang dicapai oleh seorang pegawai dalam melaksanakan tugasnya sesuai dengan tanggung jawab yang diberikan kepadanya.

Maka pengertian kinerja pegawai adalah hasil kerja perseorangan dalam suatu organisasi.Kinerja pegawai tidak dapat dilepaskan dari sumber daya yang dimiliki oleh organisasi, sumber daya yang digerakan atau dijalankan pegawai yang berperan aktif sebagai pelaku dalam upaya mencapai tujuan organisasi tersebut.

Menurut Bangun (2012) berbagai dimensi atau kriteria kinerja yang dapat digunakan untuk mengevaluasi kinerja adalah :

1. Jumlah pekerjaan

Dimensi ini menunjukkan jumlah pekerjaan yang dihasilkan individu atau kelompok sebagai persyaratan yang menjadi standar pekerjaan. Setiap pekerjaan memiliki persyaratan yang berbeda sehingga menuntut Pegawai harus memenuhi persyaratan tersebut baik pengetahuan, keterampilan, maupun kemampuan yang sesuai. Berdasarkan persyaratan pekerjaan tersebut dapat diketahui jumlah Pegawai yang dibutuhkan untuk dapat mengerjakannya, atau setiap Pegawai dapat mengerjakan berapa unit pekerjaan.

2. Kualitas pekerjaan

Setiap Pegawai dalam perusahaan harus memenuhi persyaratan tertentu untuk dapat menghasilkan pekerjaan sesuai kualitas yang dituntut suatu pekerjaan tertentu. Setiap pekerjaan mempunyai standar kualitas tertentu yang harusm disesuaikan oleh Pegawai untuk dapat mengerjakannya sesuai ketentuan. Pegawai memiliki kinerja baik bila dapat menghasilkan pekerjaan sesuai persyaratan kualitas yang dituntut pekerjaan tersebut.

3. Ketepatan waktu

Setiap pekerjaan memiliki karakteristik yang berbeda untuk jenis pekerjaan tertentu harus diselesaikan tepat waktu, karena memiliki ketergantungan atas pekerjaan lainnya. Pekerjaan yang tidak selesai tepat waktu pada suatu bagian akan menghambat pekerjaan pada bagian lain, sehingga mempengaruhi jumlah dan kualitas hasil pekerjaan.

4. Kehadiran

Suatu jenis pekerjaan tertentu menuntut kehadiran Pegawai dalam mengerjakannya sesuai waktu yang ditentukan. Kinerja Pegawai ditentukan oleh tingkat kehadiran Pegawai dalam mengerjakannya. 
5. Kemampuan kerja sama

Tidak semua pekerjaan dapat diselesaikan oleh satu orang Pegawai saja. Untuk jenis pekerjaan tertentu mungkin harus diselesaikan oleh dua orang atau lebih, sehingga membutuhkan kerja sama antarPegawai sangat dibutuhkan. Kinerja Pegawai dapat dinilai dari kemampuannya bekerjasama dengan rekan sekerja lainnya.

2) Indikator Pengukuran Kinerja

Sehubungan dengan ukuran penilaian prestasi kerja maka kinerja pegawai, menurut Robbins (2002), diukur dengan indikator-indikator sebagai berikut:

1. Kuantitas hasil kerja, yaitu jumlah produksi kegiatan yang dihasilkan atau diselesaikan. Pengukuran kuantitatif melibatkan perhitungan keluaran dari proses atau pelaksanaan kegiatan. Ini berkaitan dengan jumlah keluaran yang dihasilkan.

2. Kualitas hasil kerja, yaitu mutu yang harus dihasilkan (baik tidaknya). Pengukuran kualitatif keluaran mencemirkan pengukuran "tingkat kepuasan”, yaitu seberapa baik penyelesaiannya. Ini berkaitan dengan bentuk keluaran.

3. Ketepatan waktu, yaitu sesuai tidaknya dengan waktu yang direncanakan. Pengukuran ketepatan waktu merupakan jenis khusus dari pengukuran kuantitatif yang menentukan ketepatan waktu penyelesaian suatu kegiatan.

\section{b. Motivasi}

Seseorang yang tidak termotivasi, hanya memberikan upaya minimum dalam hal bekerja. Konsep motivasi, merupakan sebuah konsep penting studi tentang kinerja individual. Dengan demikian motivasi berarti pemberian dorongan, penimbulan motiv atau hal yang menimbulkan dorongan atau keadaan yang menimbulkan dorongan. Dapat juga dikatakan bahwa motivasi adalah faktor yang mendorong orang untuk bertindak dengan cara tertentu. Mangkunegara (2005:61) menyatakan motivasi terbentuk dari sikap (attitude) Pegawai dalam menghadapi situasi kerja di perusahaan (situation). Motivasi merupakan kondisi atau energi yang menggerakkan diri Pegawai yang terarah atau tertuju untuk mencapai tujuan organisasi perusahaan. Sikap mental Pegawai yang pro dan positif terhadap situasi kerja itulah yang memperkuat motivasi kerjanya untuk mencapai kinerja maksimal.

Teori Motivasi "Dua Faktor Fredrick Herzberg"

Di dalam bukunya, Ivancevich (2006:148-151) menjelaskan teori dua-faktor Hezberg. Hezberg mengembangkan teori isi yang dikenal sebagai teori motivasi dua faktor yang dikembangan dari teori hirarki kebutuhan menurut Maslow. Kedua factor tersebut disebut faktor ekstrinsik dan intrinsik, bergantung pada pembahasan teori. 
Faktor intrinsik yaitu daya dorong yang timbul dari dalam diri masing- masing orang dan faktor ekstrinsik yaitu daya dorong yang datang dari luar diri seseorang terutama dari organisasi tempatnya bekerja. Untuk memahami motivasi Pegawai dalam penelitian ini digunakan teori motivasi dua faktor yang dikemukakan oleh Hezberg. Adapun pertimbangan penulis adalah :

a. Teori yang di kembangakan oleh Hezberg berlaku mikro yaitu untuk Pegawai di tempat ia bekerja saja. Sementara teori motivasI Maslow misalnya berlaku makro yaitu untuk manusia pada umumnya.

b. Teori Herzberg lebih eksplisit dari teori hirarki kebutuhan Maslow, khususnya mengenai hubungan antara kebutuhan dengan performa pekerjaan.

Berikut teori motivasi "dua faktor" menurut Hezberg yang dapat dijadikan sebagai acuan guna mengukur motivasi yang dikutip dari siagian (2004) adalah sebagai berikut :

\section{Tabel 2.1}

Teori Motivasi "Dua Faktor Fredrick Hezberg"

\begin{tabular}{ll}
\multicolumn{1}{c}{ Faktor Ekstrinsik } & \multicolumn{1}{c}{ Faktor Intrinsik } \\
\hline 1. Kebijaksanaan dan Administrasi & 1. Pengakuan / Penghargaan \\
2. Supervisi & 2. Pekerjaan itu sendiri \\
3. Gaji / Upah & 3. Tanggung jawab \\
4. Hubungan antar Pribadi & 4. Penegembangan \\
5. Kondisi Kerja & 5. Keberhasilan \\
\hline
\end{tabular}

Motivasi berpengaruh positif terhadap Kinerja Pegawai, menurut ( Teruna, 2012).

H1 = Motivasi berpengaruh terhadap Kinerja Pegawai.

\section{c. Disiplin Kerja}

Disiplin kerja yang baik mencerminkan besarnya rasa tanggung jawab seseorang terhadap tugas-tugas yang diberikan kepadanya. Hal ini mendorong gairah kerja, semangat kerja dan terwujudnya tujuan organisasi, Pegawai dan masyarakat. Oleh karena itu, setiap manajer selalu berusaha agar bawahannya mempunyai kedisiplinan yang baik. Seorang manajer dikatakan efektif dalam kepemimpinannya, jika para bawahannya berdisiplin baik. Kedisiplinan dapat diartikan bilamana Pegawai selalu datang dan pulang tepat pada waktunya, mengerjakan semua pekerjaannya dengan baik, mematuhi semua peraturan perusahaan dan norma social yang berlaku (Fathoni, 2006).

Hasibuan (2006), memberikan defenisi disiplin sebagai kesadaran sikap seseorang yang secara sukarela menaati semua peraturan dan sadar akan tugas dan tanggung jawabnya. Jadi seseorang akan mematuhi / mengerjakan semua tugasnya dengan baik, bukan atas paksaan dan kesedihan. Seseorang menaati peraturan organisasi dan norma-norma sosial yang 
berlaku.Menurut Sastrohadiwiryo (2003:292) secara khusus tujuan disiplin kerja para pegawai, antara lain :

1) Agar para pegawai menepati segala peraturan dan kebijakan ketenagakerjaan maupun peraturan dan kebijakan organisasi yang berlaku, baik tertulis maupun tidak tertulis, serta melaksanakan perintah manajemen dengan baik.

2) Pegawai dapat melaksanakan pekerjaan dengan sebaik-baiknya serta mampu memberikan pelayanan maksimum kepada pihak tertentu yang berkepentingan dengan organisasi sesuai dengan bidang pekerjaan yang diberikan kepadanya.

3) Pegawai dapat menggunakan dan memelihara sarana dan prasarana, barang dan jasa organisasi dengan sebaik-baiknya.

4) Para pegawai dapat bertindak dan berpartisipasi sesuai dengan norma-norma yang berlaku pada organisasi.

5) Pegawai mampu menghasilkan produktivitas yang tinggi sesuai dengan harapan organisasi, baik dalam jangka pendek maupun jangka panjang.

Dimensi-Dimensi Disiplin Kerja

Menurut Hasibuan (2009:194) kedisiplinan diartikan jika pegawai selalu datang dan pulang tepat waktunya, mengerjakan semua pekerjaan dengan baik, mematuhi semua peraturan organisasi dan norma - norma yang berlaku. Maka dapat disimpulkan bahwa dimensi dimensi dalam disiplin kerja dapat dikelompokkan menjadi tiga diantaranya :

1) Selalu datang dan pulang tepat pada waktunya

Ketepatan pegawai datang dan pulang sesuai dengan aturan dapat dijadikan ukuran disiplin kerja. Dengan selalu datang dan pulang tepat dengan waktunya, atau sudah sesuai dengan aturan yang telah ditetapkan maka dapat mengindikasikan baik tidaknya kedisiplinan dalam organisasi tersebut.

Merupakan dimensi yang berhubungan dengan pengawasan melekat karena dengan pengawasan ini atasan aktif dan langsung untuk mengawasi perilaku, moral, gairah kerja, prestasi kerja bawahan, dan sikap Pegawai untuk dating dan pulang tepat pada waktunya.

2) Mengerjakan semua pekerjaan dengan baik

Mengerjakan semua pekerjaan dengan baik merupakan salah satu dimensi kedisiplinan, dengan hasil pekerjaan yang baik dapat menunjukkan kedisiplinan pegawai suatu organisasi dalam mengerjakan tugas yang diberikan. Hal ini berhubungan dengan kemampuan Pegawai, balas jasa dan hubungan kemanusiaan.

3) Mematuhi semua peraturan organisasi dan norma-norma yang berlaku Mematuhi semua peraturan organisasi dan norma-norma yang berlaku merupakan salah satu sikap disiplin 
pegawai sehingga apabila pegawai tersebut tidak mematuhi aturan dan melanggar normanorma yang berlaku maka itu menunjukkan sikap tidak disiplin. Merupakan dimensi yang berhubungan dengan teladan pimpinan, keadilan, sanksi hukuman dan ketegasan pimpinan agar pegawainya dapat mematuhi peraturan organisasi dan norma-norma yang berlaku.

Disiplin Kerja berpengaruh positif terhadap Kinerja Pegawai, menurut ( Putri Intan Susanti,Astadi Pangarso, 2016).

\section{H1 = Disiplin Kerja berpengaruh terhadap Kinerja Pegawai.}

\section{METODOLOGI}

1. Populasi dan sampel

Populasi merupakan gabungan seluruh elemn yang memiliki serangkaian karakteristik serupa untuk kepentingan riset ( Malhotra,2005) serta sekumpulan unsur atau elemen yang menjadi obyek penelitian,dapat berupa lembaga,individu,kelompok, dokumen. Populasi pada penelitian ini adalah pegawai negeri sipil yang berjumlah 35 orang pada kantor Dinas Sosial Kabupaten Kendal. Total seluruh tenaga kerja di kantor tersebut adalah 35 orang.

Teknik pengambilan sampel dalam penelitian ini adalah sampel jenuh atau sensus. Sangadji ( 2010 : 189) sampel jenuh adalah teknik penentuan sampel bila semua anggota populasi digunakan sebagai sampel. Jadi sampel dalam penelitian ini adalah semua pegawai kantor Dinas Sosial Kabupaten Kendal yang berjumlah 35 orang.

\section{Variabel Penelitian}

Jenis penelitian menggunakan Explanatory reserch. Menggunakan data primer, yaitu kuesioner dan kepustakaan, sampel yang digunakan berjumlah 35 Responden yaitu Pegawai Kantor Dinas Sosial Kabupaten Kendal.

\section{Definisi Operasional dan Indikator}

\begin{tabular}{lllll}
\hline Variabel & Definisi Operasional & \multicolumn{2}{l}{ Indikator } & Sumber \\
\hline Kinerja & Kinerja merupakan hasil & 1. & Ketepatan waktu & (Mangkunegara,2011), \\
Pegawai & kerja pegawai kantor & 2. & Ketrampilan & (Bangun, 2012) \\
& Dinas Sosial Kabupaten & 3. & Prestasi & \\
& Kendal. secara kualitas & 4. & Target & \\
& dan kuantitas yang & 5. & Kehadiran & \\
& dicapai oleh pegawai & 6. & Ketaatan & \\
& dalam melaksanakan & 7. & Kerjasama & \\
& tugasnya sesuai dengan & 8. & Inisiatif & \\
& tanggung jawab yang & 9. Kualitas & (Hasibuan, 2003), \\
Motivasi & diberikan kepadanya. & & & (Siagian, 2004) \\
& Motivasi kerja & A. Intristik &
\end{tabular}




$\begin{array}{lll}\text { yang timbul dari dalam } & 2 . & \text { Pengakuan } \\ \text { diri untuk melakukan } & \text { 3. } & \text { Pekerjaan itu sendiri } \\ \text { suatu pekerjaan tanpa ada } & \text { 4. } & \text { Tanggung jawab } \\ \text { paksaan dari manapun. } & 5 . & \text { Pengembangan } \\ & \text { B. Ekstristik } \\ & \text { 1. Gaji } \\ & \text { 2. Kondisi pekerjaan } \\ & \text { 3. Keamanan pekerjaan } \\ & \text { 4. Status } \\ & \text { 5. Hubungan sesama rekan } \\ & \text { 6. Perja } \\ & \text { 7. Saling membantu } \\ & \text { 8. Kerja tim }\end{array}$

3. Metode Pengumpulan Data

Teknik pengumpulan data dalam penelitian ini meliputi :

1. Field Research, meliputi:

a)Wawancara, yaitu mendapatkan informasi dengan cara bertanya langsung kepada responden (Singarimbun \& Effendi, 1995: 192). Dalam hal ini data diperoleh dengan melakukan wawancara dengan pihak pimpinan, kepala bagian, dan beberapa Pegawai untuk mendapatkan informasi yang diinginkan.

b)Kuesioner, merupakan metode pengumpulan data melalui penyebaran daftar pertanyaan yang diajukan sehubungn dengan materi penelitian kepada responden yang telah terpilih.

c)Observasi, merupakan metode pengumpulan data melalui pengamatan kegiatan sehari-hari Pegawai.

2. Library Research Yaitu dengan menggunakan studi kepustakaan dan literatur-literatur lainnya yang ada hubungannya dengan penelitian yang dilakukan di mana akan 
didapatkan data-data yang dibutuhkan oleh peneliti guna melengkapi hasil dari penelitian.

3. Dokumen yaitu semua kegiatan yang berkaitan dengan foto dan penyimpanan foto, pengumpulan, pengolahan dan penyimpanan informasi dalam bidang pengetahuan. Kumpulan bahan atau dokumen yang dapat digunakan sebagai asas bagi sesuatu kejadian, penghasilan sesuatu terbitan

4. Metode Analisis Data

Berdasarkan tujuan dari penelitian ini, maka metode analisis data yang akan digunakan dalam penelitian ini adalah Regresi Linier Berganda, Hipotesis Uji t dan Uji F serta koefisiensi Determinasi.

\section{PEMBAHASAN}

1. Dari hasil spss dapat diketahui bahwa semua variabel valid dan reliable. Pada uji asumsi klasik ( uji multikolearitas, heterokedastisitas, dan normalitas ) semua variabel memenuhi syarat, yaitu pada uji multikoleaneritas tidak terjadi multikoleaneritas, uji heterokedastiitas bahwa pada model penelitian tidak terjadi heterokedastisitas, dan uji normalitas yaitu berdidtribusi normal sehingga persyarat normalitas terpenuhi.

2. Uji Regresi Berganda

\begin{tabular}{|c|c|c|c|c|c|c|c|}
\hline \multicolumn{8}{|c|}{ Coefficients $^{\mathrm{a}}$} \\
\hline \multirow[b]{2}{*}{ Model } & \multicolumn{2}{|c|}{$\begin{array}{l}\text { Unstandardized } \\
\text { Coefficients }\end{array}$} & \multirow{2}{*}{$\begin{array}{c}\begin{array}{c}\text { Standardize } \\
\mathrm{d} \\
\text { Coefficients }\end{array} \\
\text { Beta }\end{array}$} & \multirow[b]{2}{*}{$\mathrm{t}$} & \multirow[b]{2}{*}{ Sig. } & \multicolumn{2}{|c|}{$\begin{array}{c}\text { Collinearity } \\
\text { Statistics }\end{array}$} \\
\hline & B & Std. Error & & & & $\begin{array}{c}\text { Toleran } \\
\text { ce }\end{array}$ & VIF \\
\hline (Constant) & $\begin{array}{c}37.7 \\
85\end{array}$ & 5.410 & & $\begin{array}{c}6.98 \\
4\end{array}$ & .000 & & \\
\hline Motivasi & .334 & .111 & .448 & $\begin{array}{c}3.01 \\
3\end{array}$ & .005 & .807 & 1.239 \\
\hline Disiplin & .625 & .130 & .715 & $\begin{array}{c}4.81 \\
0\end{array}$ & .000 & .807 & 1.239 \\
\hline
\end{tabular}

a. Dependent Variable: Kinerja Pegawai

Sumber : Hasil Pengolahan SPSS (2018)

Persamaan :

Kinerja Pegawai $=0,334$ Motivasi + 0,625 Disiplin Kerja $+\mathbf{e}$ 
Berdasarkan persamaan diatas maka dapat diuraikan sebagai berikut :

1. Interpretasi dari persamaan regresi berganda, yakni :

a) Jika segala sesuatu pada variabel-variabel independen dianggap konstan maka

b) kinerja pegawai sebesar 37,785 .

c) Jika terjadi penambahan atau kenaikan tingkat motivasi kerja sebesar 1 satuan, maka kinerja pegawai akan naik sebesar 0,334.

d) Jika terjadi penambahan atau kenaikan disiplin kerja sebesar 1 satuan, maka kinerja pegawai akan naik sebesar 0,625.

2. Motivasi kerja pegawai berpengaruh positif terhadap kinerja pegawai dengan koefisien regresi sebesar 0,334 tanda + (positif) pada variabel motivasi kerja pegawai menunjukkan hubungan yang searah, artinya bila usaha memotivasi kerja ditingkatkan maka akan berpengaruh terhadap meningkatnya kinerja pegawai.

3. Disiplin kerja pegawai berpengaruh positif terhadap kinerja pegawai dengan koefisien regresi sebesar 0,625 tanda + (positif) pada variabel kedisiplinan kerja pegawai menunjukkan hubungan yang searah, artinya bila disiplin kerja ditingkatkan maka akan berpengaruh terhadap meningkatnya kinerja pegawai.

\section{KESIMPULAN}

a. Kesimpulan

Hasil penelitian ini menunjukkan bahwa variabel motivasi kerja dan disiplin kerja secara bersama-sama berpengaruh positif terhadap kinerja pegawai Dinas Sosial Kabupaten Kendal. Berdasarkan hasil uji signifikan secara parsial yang dominan mempengaruhi kinerja pegawai kantor Dinas Sosial Kabupaten Kendal. adalah variabel disiplin kerja. Dari hasil analisis koefisien determinasi diperoleh nilai R Square (R2) sebesar 0,430 hal ini berarti 43,0 \% variabel kinerja dapat dijelaskan oleh variabel motivasi kerja dan variabel disiplin kerja, sedangkan sisanya sebesar 57,0 \% dapat dijelaskan oleh variabel lain yang tidak diteliti dalam penelitian ini. 


\section{DAFTAR PUSTAKA}

Hasibuan, Malayu S.P, 2006. Manajemen Sumber Daya Manusia, Edisi Revisi,PT Bumi Aksara, Jakarta.

, Anwar Prabu. 2005. Manajemen Sumber Daya Manusia Perusahaan. Bandung: PT. Remaja Rosolakarya Offset.

Mangkunegara, Anwar A.A, 2011. ManajemenSumber Daya Manusia Perusahaan, Edisi Revisi, Cetakan Kesepuluh,PT Remaja Rosdakarya Offset, Bandung.

Robbins, P. Stephen, 2001. Perilaku Organisasi, Konsep, Kontroversi, Aplikasi, Jilid I, Edisi Kedelapan, Prenhallindo, Jakarta.

Robbins, P Stephen, 2002. Prinsip - Prinsip Perilaku Organisasi, Edisi Kelima, Alih Bahasa Halida, S.E. dan Dewi Sartika, S.S, Erlangga, Jakarta.

Robbins,P Stephen,2010. Manajemen. Jilid 2, Jakarta : Erlangga

Robbins, P Stephen, 2006. Perilaku Organisasi : Edisi kesepuluh. Jakarta : PT Indeks.

Sastrohadiwiryo, Siswanto, 2003. Manajemen Tenaga Kerja Indonesia, Edisi Pertama, Cetakan Pertama Bumi Aksara, Jakarta

Siagian, 2004. Teori Motivasi dan Aplikasinya, PT. Rineke Cipta, Jakarta

Syafrizal Helmi dan Muslich Lufti, 2011. Analisis Data: Untuk Riset Manajemen dan Bisnis, USU Press, Medan.

Tika, Pabundu, 2006. Budaya Organisasi dan Peningkatan Kinerja Perusahaan,PT Bumi Aksara, Jakarta.

Wibowo dan M.Phil, 2007. Manajemen Kinerja, PT.Raja Grafindo Persada, Jakarta.

Ginting, Eva Flora, 2009. Pengaruh Disiplin Kerja Terhadap Prestasi Kerja Karyawan PT. Bank Rakyat Indonesia (Persero) Tbk. Cabang Putri Hijau. Fakultas Ekonomi Universitas Sumatera Utara.

Napitupulu. 2011. Pengaruh Disiplin dan Komitmen Karyawan terhadap Prestasi Kerja Karyawan PT. Tonga Tiur Putra Medan. Skripsi Fakultas Ekonomi Universitas Sumatera Utara. Medan.

Teruna. 2012. Pengaruh Motivasi dan kepuasan kerja terhadap kinerja karyawan pada PT. Aplikasinusa Lintasarta Medan. Skripsi Fakultas Ekonomi Universitas Muhammadiyah Sumatera Utara. Medan. 